\title{
The Temporary Safe Haven- An Australian Perspective
}

\author{
Jackie King
}

\begin{abstract}
Australia's decision to provide temporary safe haven protection to 4000 Kosovars in response to the UNHCR request for assistance in theirhumanitarian evacuation from refugee camps in surrounding countries, required quick action by the government to provide for an unprecedented legislative and service delivery framework. This paper looks at the notion of temporary protection, both in international and specifically Australian context, before describing and assessing the legislative and service delivery mechanisms that facilitated Australia's response. This paper concludes that the risk of selective intepretation of the legislation and the denial of democratic rights to the subjects of legislation, and the less than adequate service delivery to the Kosovars, and the arguable breach of its international obligations, suggests that Australia will have to think twice before engaging in such a mechanism in the future.
\end{abstract}

\section{Résumé}

Ladécision del'Australie d'offrirlaprotection d'un havre temporaire de sécuritéà 4 o00kosovarsen réponseàl'appelduHCR d'aiderà leurévacuation humanitaire de camps de réfugiés situés dans des pays avoisinants, arequisune réaction rapidede la part du gouvernement pour mettre en place un cadre législatifet de prestationde service sansprécédent. Cetarticleexamine lanotion deprotection temporaire, à la fois dans un contexte international et spécifiquementaustralien, avantdedécrire etd'évaluerlesmécanismeslégislatifset de prestation de service qui ont facilité la

Jackie King is a postgraduate student with the Department of Political Science at the University of Western Australia. She is the chairperson of the Refugee Council of Western Australiaand was a participantin 2000summer course on refugee issues at the Centre for Refugees Studies, YorkUniversity. réaction del'Australie. L'articleconclutque le risque d'interprétation sélective de la législationetle dénidedroits démocratiques à ceux qui en sont affectés, le niveau inadéquat de prestation de service aux kosovars, ainsique ce qui pourraittrès bien êtrequalifiéde violations de ses obligations internationales, tout cela suggère qu'à l'avenir, l'Australie réfléchira à deux fois avantdes'engagerdansuntelmécanisme.

\section{Introduction}

TheNATObombing of Yugoslavia from 24 March 1999 triggered a mass exodus of refugees from Kosovo. In response to a request by the UNHCR, Australia agreed to accept 4000 refugees on a temporary basis. The decision to accept the Kosovars required quick action by the government to provide for a legislative and service delivery framework, unprecedented in Australian history. This paper looks at the notion of temporary protection, both in an international and specifically Australian context, before describing and assessing Australia's response to the Kosovar crisis.

\section{The International Experience of Temporary Protection}

Article 1(A)2 of the 1951 Convention Relating to the Status of Refugees defines a refugee as a person who, owing to a "well founded fear of persecution for reasons of race, religion, nationality, membership of a particular social group or political opinion, is outside the country of his nationality and is unable, or owing to such fear is unwilling to avail himself of protection of that country; or who, not having a nationality and being outside the country of his former habitual residence, is unable, or owing to such fear, is unwilling to return to it."

In accordance with this definition, the Convention only provides a right to seek asylum, not a right to be granted asylum. However Article 33(1) of the Convention provides for the right of non-refoulement, which expressly prohibits the receiving state from expelling or returning a refugee to the frontier of territories where his or her life or freedom would be threatened, on the basis of race, religion, nationality, membership of a particular group or political opinion. Thus although a refugee is not guaranteed permanent entry into a country of asylum, that country is prohibited from returning the asylum seeker to a state where his or her life would be in danger.

This principle of non-refoulement is one of the central notions of refugeelaw, and one that State signatories to the Convention are bound to abideby. However, the practical realities of increased numbers of refugees and the continuing anti-refugee sentiment at a domestic level in many countries, have forced governments to try and compromise between the needs of their constituents and their international obligations. One of these compromises has been the development of the notion of temporary refuge.

Temporary refuge might be summarised as emergency admission on a provisional basis, solely with the aim of providing a safe haven, without commitment concerning permanent or longterm refuge in a country of refuge ${ }^{1}$ In simplest terms, temporary refuge means a prohibition on forced repatriation so long as conditions in the country of origin remain unsafe.

Within this context, protection is linked with the persistence of the causes of protection. The Convention reflects the temporary nature of refugee status in the cessation clauses of article 1C, especially paragraph $5 .^{2}$ The concept of temporary refuge, thus stands as the linkbetween the peremptory, normative aspects of non-refoulement and the continuing discretionary aspect of a State's rights in a matter of asylum as a permanent solution, and in the treatment to be accorded to those admitted. ${ }^{3}$ 
The first granting of temporary refuge was granted in 1936 when France and Britain provided safe haven to persons fleeing the Spanish Civil War, for the duration of the conflict. Further historical examples include the temporary asylum offered for approximately nine months in November 1956 by Austria and Yugoslavia to 200,000 persons fleeing the unsuccessful uprising in Hungary. ${ }^{4}$ In 1968 Austria again offered a similar type of temporary asylum to people fleeing the Soviet invasion of Czechoslovakia.

The conceptualisation of the term however, came about only in the 1970s with the Vietnamese Boat PeopleCrisis. The first mention in official documents comes in Conclusion 15 of the UNHCR Executive Committee in 1979, which was concerned with the reception of the Boat People in Coastal States. ${ }^{5}$ The ExecutiveCommittee stressed the humanitarian obligation of coastal states "to allow vessels in distress to seek haven in their waters and to grant them asylum, or at least temporary refuge", to protect those on board seeking it. ${ }^{6}$ Similarly, it noted that in cases of "large scale influx, persons seeking asylum should always receive at least temporary refuge" and that states "faced with a large scale influx should as necessary and at the request of the state concerned, receive immediate assistance from other states in accordance with the principle of equitable burden sharing."

At its $31^{\text {st }}$ session in 1980, the Executive Committee affirmed the need for the "humanitarian legal principle of nonrefoulement to be scrupulously observed in all situations of large influx". At this point, the Executive Committee stressed the exceptional character of temporary refuge, and recognised that temporary refuge needed defining and further examining. ${ }^{8}$ In 1981 the Committee adopted the substantive contents of temporary refuge, stressing in particular the need for states of first refuge in situations of mass influx to grant admissions to their territory, preferably on a permanent, but at least on a temporary basis. ${ }^{9}$ The High Commissioner further noted that there has been a "clear recognition that persons to whom only temporary asylum can be granted should be treated according to basic minimum standards." 10 The High Commissioner in 1985 identified temporary refuge as being encompassed within the "universally recognised" principle of non-refoulement. ${ }^{11}$

The language of temporary protection re-emerged recently in response to the crisis in the former Yugoslavia. As part of the "comprehensive response" temporary refuge was considered a "flexible and pragmatic means of affordingneeded protection tolarge numbers of people fleeing human rights abuses and armed conflict... who might have otherwise overwhelmed asylum procedures."12 A 1992 statement by UNHCR put its position as being that "persons fleeing from the former Yugoslavia who are in need of international protection should beable to receive it on a temporary basis." 13

Despite this, the Executive Committee of the UNHCR has so far stopped short of expressly endorsing the institution of temporary refuge. This is a result of a mixture of terminological squabbles and concerns that the formalisation of State practice in granting temporary, rather than permanent refuge "might be counter productive in 'legitimising' attitudes of lesser, rather than greater effort on the part of States in the provision of protection to persons in need." 14

The common practice of temporary refuge, has in fact, led some commentators to call the notion of temporary refuge a customary norm of international law, despite the absence of official endorsement by the UNHCR. Such law commonly fills gaps created where actual situations divergefrom what is covered by existing treaties. It has been argued that the development of the notion of temporary refuge typifies this phenomenon of norm creation, and is in fact an acceptable practice. ${ }^{15}$

Temporary protection thus serves three purposes: Firstly, administrative and economic resources are saved through the absence of a full asylum procedure assessing the individual claims, by applying a prima facie group determination. Secondly, politically, it becomes easier to return the refugee if the situation in the country of origin changes. In this way, a signal is sent to the refugee that their stay in the host country is temporary. Lastly, a signal is sent to the public at large that this refugee situation is purely a matter of protection with no element of voluntary migration. ${ }^{16}$

\section{Australia's Experience of Temporary Refuge}

Australia acceded to the Refugee Convention on 22 January 1954 and the 1967 Protocol on 13 December 1973. The terms of the Convention and Protocol are incorporated by reference into Australian law by section 36 of the Migration Act (1958) which provides for a class of protection visas and applies the Convention definition of refugee to such status determination. The Aus. tralian government, like many others, has determined that in certain cases, temporary refuge, (usually implemented by the creation of additional classes of temporary visa) is the best means of simultaneously fulfilling its international obligations and appeasing an increasingly disconcerted public.

Over the years, Australia has seen a number of temporary visas granted to people already in Australia who, were unable to return to their home countries, such as Iraq, Lebanon and Sri Lanka. Then, as a result of the tragic events in Tienanmen Square in 1989, four-year temporary visas were granted to the affected Chinese in Australia at the time, with these later being converted to permanent visas. In each of the above cases, the granting of the visas served many practical purposes, including the desire to regularise the status of people whose return would be difficult and to reduce pressure on refugee status determination procedures. ${ }^{17}$ However, it was not until the events in the former Yugoslavia and then Kosovo that the notion of temporary refuge gained prominence again, and resulted in the development, implementation and execution of a new legislative framework for temporary protection. 


\section{The Legislative Framework}

The creation of a temporary protection visa for the Kosovars took the concept of temporary protection to a new Australian league. It differed from all previous applications in many fundamental ways. This was the first time that such visas were granted to people outside Australia; the Australian Government arranged and funded their travel to Australia; and all basic needs were provided for while residing in the Safe Haven sites. This section of the paper seeks to provide an overview of the Australian legislative framework created in response to the Kosovar crisis, while the following section provides an evaluation of the legislation in the context of Australia's international obligations.

The Migration Legislation Amendment (Temporary Safe Visas) Act 1999 (Commonwealth) ("the Act") provided this new legislative framework. Thelegislation created a new subdivision of the Migration Act 1958 (Commonwealth), introducing into it far reaching provisions which have been criticised for limiting the rights of those granted protection. Notably, the Act was passed unanimously, with the support of the Labor Party, the Democrats and Greens as well as independent Senators Harradine and Coulston. In fact, one of the pre-conditions of entry for the Kosovars was that Parliamentary opposition parties agreed to the passage of retrospective legislation to formalise these limitations. ${ }^{18}$ Section 4 of the Act therefore states that an application made before the commencement of the Act "ceases to be valid" on the Act's commencement, "despite any provision of the Migration Act or any other law." In order to "avoid doubt", section 4 states that this rule applies even if the application is the subject of a review or appeal to "a review officer, body, tribunal or court."

Under the Act, the Minister has a wide discretion to, by notice in the Gazette, extend or shorten the period of a safe haven visa. A visa may be shortened if "in the Minister's opinion, temporary safe haven in Australia is no longer necessary for the holder of a visa because of changes of a fundamental, durable and stable nature in the country concerned." However, in this case, the Minister also has a power, which must be exercised personally, to exempt safe haven visa holders from removal, "if the Minister thinks it is in the public interest".

There are also provisions that render invalid any application for a different class of visa after the enactment of the Act. Section $91 \mathrm{~K}$ provides that if the holder of a safe haven visa applies, or purports to apply for a visa other than a temporary safe haven visa, then "that application is not a valid application". The Australian government claimed that such an approach ensured that Australia could meet its commitment to provide temporary safe haven and also effectively maintain the integrity of Australia's migration and humanitarian programmes. ${ }^{19}$ Section $91 \mathrm{H}$ that explains that "the Parliament considers that a non-citizen who holds a temporary safe haven visa, or who has not left Australia since ceasing to hold such a visa, should not be allowed to apply for a visa other than a temporary safe haven visa."

\section{Assessment of Australia's Treatment}

Australia's treatment of the Kosovar refugees was surrounded by controversy from the outset. The Howard government had initially ruled out taking any Kosovars at all. However, this stance was dramatically reversed when Cabinet met on 6 April and formally decided to admit 4000 refugees in response to a request from the UNHCR. In real terms, the announcement came after the US unveiled plans to place Kosovar refugees on the US naval base in Cuba and urged its NATO partners to make similar provisions. Just four days later, the Howard government froze its offer totake 4000 people, when NATO's European members objected to the US inspired airlift scheme, fearful that it would strengthen the hand of the Milosevic government in Yugoslavia. Finally, three weeks later on 1 May, the Australiangovernment re-activated the offer, again following an overnight request from the UNHCR. ${ }^{20}$

There has been much speculation as to whether Australia properly fulfilled its international obligations with the enactment and implementation of the new Act. Article 34 of the Convention provides that states shall facilitate the naturalisation of refugees. This suggests that states have an obligation to look for a durable solution for refugees, which may include settlement of refugees within their territories. ${ }^{21}$ The Australian legislation however, seemed to be motivated by a desire to discourage the Kosovars from seeking to remain in Australia. The inability of people granted temporary protection to apply for permanent protection, and the "invalidation" of any applications made priort the enactment of the legislation, suggests that the Australian government acted in breach of its international obligations in this respect.

The fact that the legislation prohibited the application by the safe haven visa holders, for a different visa, including a protection visa which would provide them with permanent status, was subject to much criticism. A statement by UNHCR's Director of the Division of - International Protection in reference to Australia's Safe Haven legislation, reinforced these criticisms:

At law, the Convention cannot be made unavailable for persons for whom it was intended, even while its application can be delayed. Put another way, temporary protection arrangements should be applied without prejudice to the grant of refugee status to be entitled, where it is necessary to ensure protection against continued threat. ${ }^{22}$

Further, the addition of section $500 \mathrm{~A}$ to the Migration Act was seen as undermining Australia's humanitarian commitment. This section empowered the Minister to refuse or cancel a temporary safe haven visa, and to exempt such decisions from the requirements of procedural fairness and other grounds for legal challenge. This arguably breaches Article 16 of the Convention, which states that refugees shall have access to the courts. There are vague and sweep- 
ing provisions in the legislation, which entitle the Minister to refuse or cancel visas on grounds such as: bad character, criminal conduct, having an association with other suspected of criminal conduct, harassment, intimidation, molestation or stalking, vilifying others or inciting discord, representing a "danger to the Australian community." Thus, these safe haven visas could be denied or cancelled on grounds of "national security" and "prejudice to Australia's international relations". The Minister only has to be of the opinion that "there is significant risk" of detrimental conduct. That is, no actual misconduct needs to take place. This raises the danger of the refugees' interests being subordinated to the Australian government's relations to the foreign countries. ${ }^{23}$

Moreover, the rules of natural justice are excluded from the Act.In making his decisions, the Minister "does not have a duty to consider" whether to exercise any power, whether requested to do so by the non-citizen or any other person "or in any other circumstances". Although the Minister must notify the applicant of any decision relating to his or her status, failure to do so does not affect the validity of the decision. Refusals and cancellations automatically apply to applicant's immediate family members, even if the latter are not notified of the decision. These measures seem designed to prevent applicant's children, including any children newly born in Australia from acquiring any rights to stay. ${ }^{24}$ Further, a decision to refuse to grant, or to cancel a temporary safe haven visa is not a "reviewable decision"- there is no right of appeal to the Refugee Review Tribunal, Migration Review Tribunal or the Federal Court.

In fact, Ms Graydon a member of the Legal and Constitutional References Committee that considered the legislation, expressed her doubts about these provisions:

We are concerned at the notion of temporary asylum here in Australia. We are concerned that to accept a safe haven visa people forfeit in the process many of their rights in terms of that visa being covered by rule of law. We are concerned that it may be a precedent that leads to changes in the way asylum processes happen here in Australia. We are concerned that it may well constitute a breach of international obligations under the Refugee Convention and the Universal Declaration of Human Rights. All of those concerns remain well intact. $^{25}$

However, it was not just the government's legislative framework that was subject to criticism. The treatment of the Kosovars, during the period of their stay, in terms of the standard of accommodation provided, the quality of service delivery, as well the various prohibitions on work rights and medical attention has also been criticised as breaching the spirit (if not the word) of the Convention.

Article 7 of the Convention states that refugees should be accorded at least the same treatment as is accorded aliens generally. Article 17 of the Convention provides that states shall accord to refugees lawfully within their country the most favourable treatment accorded to nationals of the country in relation to the right towork. Chapter IV makes similar provisions regarding housing ${ }^{26}$, public education ${ }^{27}$ and social security ${ }^{28}$.

The "safe haven" sites chosen for the refugees-disused and semi-used military barracks, usually in remote locations, was insensitive and clearly did not constitute the same treatment as is accorded aliens generally. Sending traumatised victims of war to military bases, isolated from the Albanian communities provoked criticism from the Ethnic Community Council of NSW and the Australian-Albanian Association. ${ }^{29}$ The poor conditions at one site the Singleton military base, 230 kilometres north of Sydney, led three busloads of refugees to refuse to disembark on 14 June. They objected to the lack of toilet and bathroom facilities, inadequate heating and protection from the weather, and the absence of privacy for family groups. ${ }^{30}$

Further, none of the Kosovars was entitled to Medicare benefits, or any social security. The governmentempha- sised that the provision of clothes, meals, health care, counselling and schooling was confined to the barracks. Those who wanted to live independently only received $\$ 20$ per week for living expenses per adult, plus $\$ 5$ a child (this was increased to $\$ 27$ and $\$ 10$ respectively on 1 June 1999). On 30 June, the Minister announced that the refugees could only work a maximum of 20 hours per week, but would then lose their allowances.

Moreover, the manner in which the Kosovars were returned to Kosovo constituted a failure by the Australian government to abide by its international obligations. In July 1999, the UNHCR assessed the situation in Kosovo as being secure enough for most of the Kosovar evacuees to return home. Having regard for the extra difficulties likely to be encountered by people returning to the Kosovar winter, the Government made available a winter reconstruction allowance of $\$ 3000$ per adult and $\$ 500$ for each child under 18 for those who returned to Kosovo between 31 August and 30 October $1999 .{ }^{31}$ On 18 October 1999, the Minister told the House of Representatives that he would extend the deadline to November 30, but "if people remain in Australia after their visas have expired, there is an obligation upon my Department to detain them and to remove them from Australia." 32

This policy breaches the refoulement principle enshrined in Article 33 of the Convention. Despite the government's rhetoric and purported evidence to support the return of the Kosovars, welfare groups and non-government organisations claimed that many Kosovars would be placed at risk if returned. Those at risk included: ethnic minorities and people from mixed marriages; draft age males who could have been considered to have evaded KLA conscription; people who could be perceived as having supported the Serb regime; female headed households without male support; peoplefrom areas in which ethnic Albanians are a minority, including southern Serbia; and victims of extreme violence. ${ }^{33}$ 
Despite this, return was justified by the Minister on the basis of the undertakings of the Kosovars who said they would return. However, these undertakings were signed at a time that the NATO offensive was still underway and there was noclarity about the future shape of Kosovo nor about any potential risks upon return. Irrespective of this, the Minister and Department insisted on the Kosovars return. By the beginning of April, there were 498 Kosovars left in Australia. Immigration Minister Ruddcok extended further protection to 130 Kosovars, mainly for medical reasons. He also found that 110 could apply for protection visas and two for partner visas on the basis of having a partner in Australia. ${ }^{34}$ The remaining 259 were returned to Kosovo in mid April. ${ }^{35}$

\section{International Comparison}

UNHCR made its request for assistance to 30 countries around the world, each with various ties to the Kosovar refugees. It is interesting to compare the experience of the Kosovars in Australia with other Western countries. Of the 7300 Kosovars evacuated to Canada, either under the Humanitarian Evacuation Program or the Family Reunification Program, over 5000 remained and became eligible for residency status. ${ }^{36}$ Approximately one in three of the 14,300 Kosovars who came to the United States returned home under the US government's funded return program, while the rest remain. ${ }^{37}$ In contrast to the generous US and Canadian experience, Germany's treatment of the Kosovars has been less than favourable. Most of the 170,000 Kosovar refugees remaining in Germany and who refused aUS\$1000 incentive to return, have appealed against the expulsion decision made against them. ${ }^{38}$ However, the German government still insists on having them all returned by the end of the year. In Switzerland, around 30,000 Kosovar refugees were affected by the deadline of 31 May 2000 to leave. Nearly 19,000 accepted financial incentives to return home by the end of last year. Of the more than 4,000 refugees who signed up for a second phase of the vol- untary program, around 1, 600 have so far gone back as of April this year. ${ }^{39}$ Some 10,500 remaining in Switzerland will be forced to return in the latter half of 2000.

The various responses to the Kosovar crisis indicates the extent to which international burden sharing and co-ordination is limited by domestic requirements and public opinion. The European Council on Refugee and Exiles, the peak non-government organisation in Europe, has recently developed a complimentary policy in temporary protection. The main points of their policy include the notion that temporary protection represents a reasonable administrative policy only in an emergency situation where individual refugee status is not immediately practicable and where temporary protection will ensure admission to the territory. Further, it should not be applied in any way that erodes existing forms of protection, such as the Convention. The rights afforded should include, as a minimum, the right to family unity, education, social assistance to cover basic needs health care, engagement in gainful employment, identity documents as well as explanation to both refugees and citizens of the host state of how these rights might be exercised. ${ }^{40}$

\section{Conclusion}

There is no question that it is difficult to create a policy which simultaneously allows those granted temporary protection to live a fruitfullife in the country of asylum, and which keeps the individual asylum seeker's mind open to the possibility of returning home. Australia's experience with the Kosovar refugees was problematic in a number of regards and arguably breached its international obligations. The questionable nature of Australia's actions potentially places the concept of temporary protection in international disrepute. There is now a question of whether Australians would be willing to act in this manner upon UNHCR's request in the future, and whether the Australian public would support temporary protection as enshrined in the Act, given the scope for selective interpretation and the denial of democratic rights that it provides for.

\section{Notes}

1. J.P. Fonteyne, "Burden Sharing: An Analysis of the Nature and Function of International Solidarity in Cases of Mass Influx of Refugees" Australian YearBook of International Law Vol. 8, No. 1, 1978-80, p. 174.

2. Which states that the Convention shall cease to apply to a person if: (5) He can no longer, because the circumstances in connection with which he has been recognised as a refugee have ceased to exist, continue to refuse to avail himself of the protection of the country of his nationality.

3.Goodwin-Gill, G. The Refugee in International Law., Oxford: Clarendon Press, 1996, p.202.

4.J. Thorburn, "Transcending Boundaries: Temporary Protection and burden Sharing in Europe" International Journal of Refugee Law, Vol. 7, No. 3, 1995, p.464.

5. Executive Committee of the High Commissioner's Program, Conclusion No 15 ( $x x x$ ) Refugee Without an Asylum Country, 1979; Ibid., n. 25, p.467.

6.Goodwin-Gill, op. cit., p. 198.

7. UNHCR, Report of the 30th Session, UN Doc A/AC.96.559 para 88.1(d), 1979; Ibid., n 140, p.198.

8. Thorburn, op. cit., n.25, p. 467.

9.Fonteyne, op.cit., p.174.

10.UNHCR, Note on International Protection,UN Document. A/AC.96/ 592, 1981; D. Perluss. and J. Hartman, "Temporary Refuge: Emergence of a Customary Norm", Virginia Law Journal, Vol. 26, No. 3, 1986, pp.571-2.

11. Ibid., p572.

12. UNHCR, Note on International Protection, UN Doc A/AC.96/815, para.25; 1993; Note on International Protection A/ AC.96/830, paras. 45-51, 1994; GoodwinGill, op. cit., p. 200;

13. UNHCR Background Note: Comprehensive Response to the Humanitarian Crisis on the Former Yugoslavia, Informal Meeting on Temporary Protection Geneva, 21 Jan 1993; Thorburn, op. cit., n. 26, p.467.

14. Fonteyene, op. cit., p.174.

15. D. Perluss and J. Hartman, op. cit., "Temporary Refuge:Emergence of a Customary Norm", Virginia Law Journal, Vol. 26, No. 3, 1986, p.557.

16. M. Kjaerum, M. "Temporary Protection in Europe in the 1990s" International Journal of Refugee Law, Vol. 6, No. 3, 1994, p.449.

17. Refugee Council of Australia, Newsletter, Spring 1999, p.4. 
18.M. Head, "TheKosovarand Timorese 'Safe Haven' Refugees: A Test Case For Democratic Rights" Alternative Law Journal Vol. 24, No. 6. December 1999, p.280.

19. Sen. I Campbell, Migration Legislation Amendment (Temporary Safe Haven Visas) Bill 1999: Second Reading, 21 April 1999, p.3975 at http:// www.aph.government.au/hansard/index/htm.

20. Head, op. cit., p.281.

21 P. Mathew and R. Zalewski, "Refugee Law Policies and Procedures" Law Institute Journal, April 1992, p.297.

22. Refugee Council of Australia, Newsletter, March 2000, p.8.

23. Head, op. cit., p.281.

24. Ibid., p.283.

25. Legal and Constitutional References Committee Operation of Australia's Refugee and Humanitarian program, 29 July 1999 at http://www.aph.government.au/ hansard/index/htm.

26. UN, Convention Relating to the Status of Refugees, 1951, Article 21.

27. UN, Convention Relating to the Status of Refugees, 1951, Article 22.

28. UN, Convention Relating to the Status of Refugees, 1951, Article 23.

29. Head, op. cit., p.281.

30. Ibid., p.281.

3 1. < h t t p://www . immi.gov.au/ immigfactsheet 62>.

32.Head, op. cit., p.281.

33. Refugee Council of Australia "Return of Kosovars" Media Release 13 April 1999.

34. "Kosovars to Return Home This Week" Ministerial Press Release PS 033/2000 at http://www.immig.gov.au.

35.Ibid.

36. "Australia: Kosovars Agree To Go" Refugees Daily, 13 April 2000 at http:// unhcr.ch/refoworld.
37. "USA: Kosovars Choose To Stay" Refugees Daily 20 April 2000 at http:// unhcr.ch/refworld.

38. "North America: Kosovars enjoy longer welcome" Refugees Daily 16 May at http:/ /www.unhcr.ch/refworld.

39. "Switzerland: Deadline Looms for Kosovars' Repatriation" Refugees Daily 24 April 2000 at http://unhcr.ch/ refworld.

40 Refugee Council of Australia, The Size and Composition of the 2000-2001 Humanitarian Program: Views from the Community Sector, February 2000, p.28.

\section{References}

"Australia: Kosovars Agree To Go" Refugees Daily, 13 April 2000 at http://unhcr.ch/ refoworld.

Campbell, Sen. I. Migration Legislation Amendment (Temporary Safe Haven Visas) Bill 1999: Second Reading, 21 April 1999, p.3975 at http:// www.aph.government.au/hansard/in. $\mathrm{dex} / \mathrm{htm}$.

Fonteyne, J.P. "Burden Sharing: An Analysis of the Nature and Function of International Solidarity in Cases of Mass Influx of Refugees" Australian YearBook of International Law Vol. 8, No. 1, 1978-80, pp. 162-188.

Goodwin-Gill,G. The Refugee in International Law Oxford:Clarendon Press, 1996.

Head, M. "The Kosovar and Timorese 'Safe Haven' Refugees: A Test Case For Democratic Rights" Alternative Law Journal Vol. 24, No. 6. December 1999, pp. 270-283.

http://www.immi.gov.au/immigfactsheet 62.

Kjaerum, M. "Temporary Protection in Europe in the 1990s" International Journal of Refugee Law, Vol. 6, No. 3, 1994, pp.443-456.

"Kosovars to Return Home This Week" Ministerial Press Release MPS 033/2000 3 April 2000 at http://www.immi.gov.au.
Legal and Constitutional References Committee Operation of Australia's Refugee and Humanitarian program, 29 July 1999 at http://www.aph.government.au/ hansard/index/htm.

Mathew, P. and Zalewski, R. "Refugee Law Policies and Procedures" Law Institute Journal, April 1992, pp297-301.

Migration Act 1958 (Commonwealth).

Migration Legislation Amendment (Temporary Safe Visas) Act 1999 (Common. wealth).

"North America: Kosovars enjoy longer welcome" Refugees Daily 16 May at http:// www.unhcr.ch/refworld.

Perluss, D. and Hartman, J. "Temporary Refuge: Emergence of a Customary Norm", Virginia Law Journal, Vol. 26, No. 3, 1986, pp.551-626.

Refugee Council Of Australia "Return of Kosovars" Media Release 13 April 1999.

Refugee Council of Australia, Newsletter, March 2000.

Refugee Council of Australia, Newsletter, Spring 1999.

Refugee Council of Australia, The Size and Composition of the 2000-2001 Humanitarian.

Program: Views from the Community Sector, February 2000.

“Switzerland: Deadline Looms for Kosovars' repatriation" Refugees Daily 24 April 2000 at http://unhcr.ch/refworld.

Thorburn, J. "Transcending Boundaries: Tem. porary Protection and Burden Sharing in Europe" International Journal of Refugee Law, Vol. 7, No. 3, 1995, pp. 459-479.

United Nations, Convention Relating to the Status of Refugees, 1951.

United Nations, Protocol Relating to the Status of Refugees, 1967.

"USA: Kosovars Choose To Stay" Refugees Daily 20 April 2000 at http://unhcr.ch/ refworld. 口

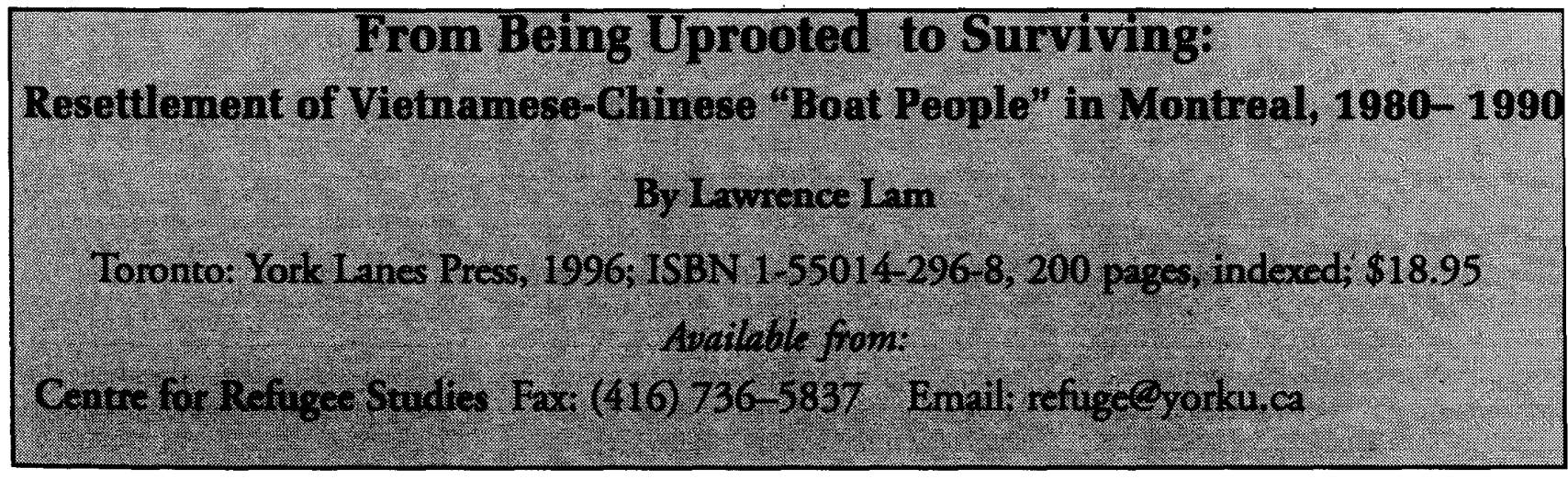

